\title{
Staging Lesbian and Gay New York
}

\section{Citation}

Bernstein, Robin. 2010. Staging lesbian and gay New York. In The Cambridge Companion to the Literature of New York, ed. B. Waterman and C. R. K. Patell, 202-217. Cambridge University Press.

\section{Permanent link}

http://nrs.harvard.edu/urn-3:HUL.InstRepos:3659696

\section{Terms of Use}

This article was downloaded from Harvard University's DASH repository, and is made available under the terms and conditions applicable to Other Posted Material, as set forth at http:// nrs.harvard.edu/urn-3:HUL.InstRepos:dash.current.terms-of-use\#LAA

\section{Share Your Story}

The Harvard community has made this article openly available.

Please share how this access benefits you. Submit a story.

\section{Accessibility}




\section{I4 \\ ROBIN BERNSTEIN \\ Staging lesbian and gay New York}

New York, more than any other city, unapologetically names its center for theater and drama: Broadway is the axis surrounded by concentric rings of off-Broadway and off-off-Broadway - marking, respectively, mainstream, margin, and fringe. Anything beyond the shores of Manhattan is designated, sometimes with condescension, "regional theater."

Lesbian and gay drama maps onto this topography. The history of scripted live performances by or about lesbian, gay, bisexual, transgender, and queer people in New York City is the history of a vexed relationship with Broadway, the mainstream visibility it offers, and the politics and aesthetics it polices. Broadway is an object of desire, a longed-for sign of success that can seduce theater practitioners toward conservative aesthetics and politics, away from radical experimentation and social engagement. Broadway spotlights a few extraordinarily talented queer playwrights - often but not always white gay men - while routinely eclipsing equally brilliant people of color, white lesbians, and feminists of all stripes. But theater practitioners who refuse and are refused by Broadway have created other venues, and the syncopation between these sites and Broadway, between the experimental and the established, characterizes New York's theater scene.

Prior to the twentieth century, plays incorporating cross-dressing were common, but a critical mass of plays that included identifiably non-heterosexual

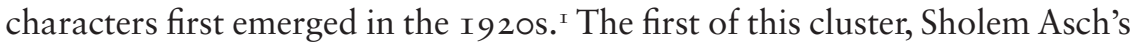
God of Vengeance, was a Yiddish-language play about a Jewish brothelkeeper whose daughter has an affair with a prostitute. God of Vengeance opened on the Lower East Side before it was translated into English and moved to the Apollo Theater on Broadway in I923. The play had received critical acclaim for its downtown production in Yiddish, as well as for international productions in German, Russian, and Italian. The Broadway debut, however, met with a police raid and charges of obscenity. ${ }^{2}$ Two other plays featuring same-sex desire, Edouard Bourdet's The Captive (I926) and Mae West's The Drag (1927), soon followed, and police raided these as well. 
Backlash against these early dramas manifested in the passage of the Wales Padlock Act of 1927, which empowered the police to padlock closed, for one full year, any theater showing a play that could "tend to the corruption of youth or others" by including "sex degeneracy or 'perversion.'” 3 This law chilled playwrights and producers, and partly as a result of it, dramas of the mid twentieth century tended either to kill off lesbian or gay characters (as in Lillian Hellman's The Children's Hour [r934]) or to subsume same-sex desire to subtext (as in many works by Noel Coward).

Gay male subtext - real or imagined - provoked some critics' homophobic hysteria. At mid-century, a handful of drama critics accused playwrights of installing homosexual - specifically, degenerate homosexual - subtext in ostensibly non-gay plays. Richard Schechner criticized Edward Albee's Who's Afraid of Virginia Woolf? for its alleged "morbidity and sexual perversity which are there only to titillate an impotent and homosexual theater audience"; Robert Brustein described Albee's The Zoo Story as having a "masochistic-homosexual perfume"; and the New York Review of Books published Philip Roth's review of Albee's Tiny Alice under the title, "The Play that Dare Not Speak its Name." 4 The accusation that gay playwrights disguised naturally depraved gay characters as unnaturally depraved heterosexual characters reached its apex in Stanley Kauffmann's I966 New York Times article, "Homosexual Drama and its Disguises." In this article, Kauffmann argued that social taboos prevented openly gay plays from being staged, and that therefore "the homosexual dramatist ... has no choice but to masquerade" homosexual characters as heterosexual ones and thus to "invent a two-sex version of the one-sex experience he really knows." 5 Referring obliquely to Albee, Tennessee Williams, and William Inge, Kauffmann accused gay playwrights, first, of disguising decadent homosexuals as heterosexuals and thus libeling heterosexuals, and, second, of critiquing heterosexuality and "sublimat[ing] social hatreds" into "lurid violence" and "viciousness toward women" (Kauffmann took no issue with non-lesbians such as Frank Marcus or Jean-Paul Sartre writing plays that featured psychopathic lesbians; nor with playwrights who weren't gay men, such as Mae West, depicting suicidally miserable gay male characters). ${ }^{6}$ Kauffmann called for "social and theatrical convention" to be "widened so that homosexual life may be as freely dramatized as heterosexual life" - not to improve the lives of gay people, but rather to curb gay playwrights' urge to "vent their feelings in camouflaged form." 7

Kauffmann's wish was soon realized, although in ways Kauffmann probably never envisioned. In the years immediately before the Stonewall Rebellion of 1969, with which many historians mark the beginning of the modern gay and lesbian rights movement, plays with gay male content 
began to receive production away from Broadway's glare. Gay playwright Joe Cino's Greenwich Village venue, the Caffe Cino, staged openly gay plays by playwrights such as Lanford Wilson, Doric Wilson, William Hoffman, and Robert Patrick. In 1967, Charles Ludlam founded the Ridiculous Theater Company, whose actors used drag to question, mock, and re-write gender. A watershed moment came in I968 with the off-Broadway staging of Mart Crowley's The Boys in the Band. In this play, set in the East Fifties in Manhattan, a group of gay men gather to celebrate their friend Harold's birthday. The characters bait and taunt each other, and the play climaxes in a game in which each character must telephone someone and tell him he loves him. The one supposedly straight guest, Alan, calls his wife, and the play ends with the implication that Alan wanted to come out, but the flamboyance and bitterness of the other party guests persuaded him back into the closet. Some gay men were repulsed by Crowley's campy and self-pitying characters, but others welcomed the play as either sympathetically realistic or kitschy. ${ }^{8}$ Regardless of one's assessment of the play, The Boys in the Band "undeniably" constituted "a turning point in the evolution of gay theater," as the critic Don Shewey notes. ${ }^{9}$ The play's popularity in and beyond New York brought a new level of visibility to gay theater and to homosexuality in general.

In the same period, lesbian and bisexual women playwrights, both white and of color, reshaped drama in and beyond New York - but often did so without including lesbian content. Lorraine Hansberry's I959 A Raisin in the Sun inaugurated and invigorated a tradition of realism in African American theater; Cuban-American Maria Irene Fornes emerged as a leading force in New York's avant-garde theater of the I960s (some of her later plays, including the I977 Fefu and Her Friends, included lesbian characters); and Megan Terry arguably invented the rock musical with Viet Rock, an anti-war piece that debuted at La Mama in I966 and whose theatrical progeny include Hair (1967), Rent (1996), and Hedwig and the Angry Inch (1997).

One of the actors in Viet Rock was Muriel Miguel, a member of the Kuna and Rappahannock Native American nations and a founding performer of the Open Theater. In I975, Miguel co-created the feminist Native American company, Spiderwoman Theater, with her heterosexual sisters Gloria Miguel and Lisa Mayo. The troupe, which is today one of the oldest feminist theater troupes still in existence, developed a powerful aesthetic that combines story-weaving with improvisation, a burlesque performance style, and bawdy wit to attack racism and sexism. ${ }^{\text {IO }}$ Much of Spiderwoman Theater's drama reflects the sisters' lives in New York City; for example, Sun, Moon, and Feather (I980) was “inspired by their childhood” in Brooklyn's Red Hook neighborhood, and The Three Sisters from Here to There (I982) replaced 
Chekhov's The Three Sisters' dreams of Moscow with three Brooklyn sisters' dreams of Manhattan. ${ }^{\text {II }}$

While on tour in Berlin in I977, Spiderwoman lost its costumes in transit. Faced with this emergency, the troupe contacted Hot Peaches, a New York male drag company that happened also to be in Berlin, to borrow some costumes. When the two troupes connected, Lois Weaver, a non-Native member of Spiderwoman, fell in love with Peggy Shaw, a butch lesbian member of Hot Peaches. Shaw left Hot Peaches to join Spiderwoman for Cabaret: An Evening of Disgusting Songs and Pukey Images (1979), but soon Shaw and Weaver both left Spiderwoman to strike out on their own. ${ }^{\mathrm{I} 2}$ The ensuing personal and professional partnership between Shaw and Weaver became one of the most fecund in New York's theater history. In I980, the two collaborated on WOW (Women's One World), an international women's theater festival that was staged in the Electric Circus at St. Mark's Place. The tremendous success of that festival, which included thirty-six performances from eight countries, led to the founding of the WOW Café, a permanent East Village theater space that continues to foster innovative theater. ${ }^{13}$

At WOW, Shaw and Weaver teamed up first with Pam Verge and Naja Beye and later with Deb Margolin to create the troupe Split Britches, which combined a Spiderwoman-inspired sense of free-associative play and raunchy humor with a sexy, campy centering of butch-femme and "eclectic combinations of fastidious attention to realistic detail with bizarre flights of surrealistic fantasy." ${ }^{\text {I4 }}$ Split Britches innovated a method of playwriting rooted in fantasy, desire, and improvisation. As Shaw describes the process:

$[\mathrm{W}] \mathrm{e}$ get together in a room and we list everything that we hate, that we love. And we think, what's our fantasy? "OK, this time, this show, I want to be a girl, and I wanna be bad, and I wanna sing the blues." You just make all your lists of fantasies, and then you practice every morning. We get together for weeks and we just start putting it together, totally from desire, from fantasy, not having any idea what it's going to be. ${ }^{15}$

Through this method, Split Britches has created many shows including Upwardly Mobile Home (I984; see Figure I4), Little Women - The Tragedy (I988), Lesbians Who Kill (I992), and most recently Miss America (2008). ${ }^{16}$ The troupe has earned a cascade of honors, including four OBIE Awards and a Jane Chambers Award, and has energized a generation of feminist scholars and theater critics. Weaver, Shaw, and Margolin have each pursued solo careers: Margolin, who is straight, has written eight full-length performance pieces and won a I999-2000 OBIE award, and she currently teaches playwriting at Yale University. Lois Weaver, now lecturer in Contemporary Performance at Queen Mary University of London, performs solo as the 


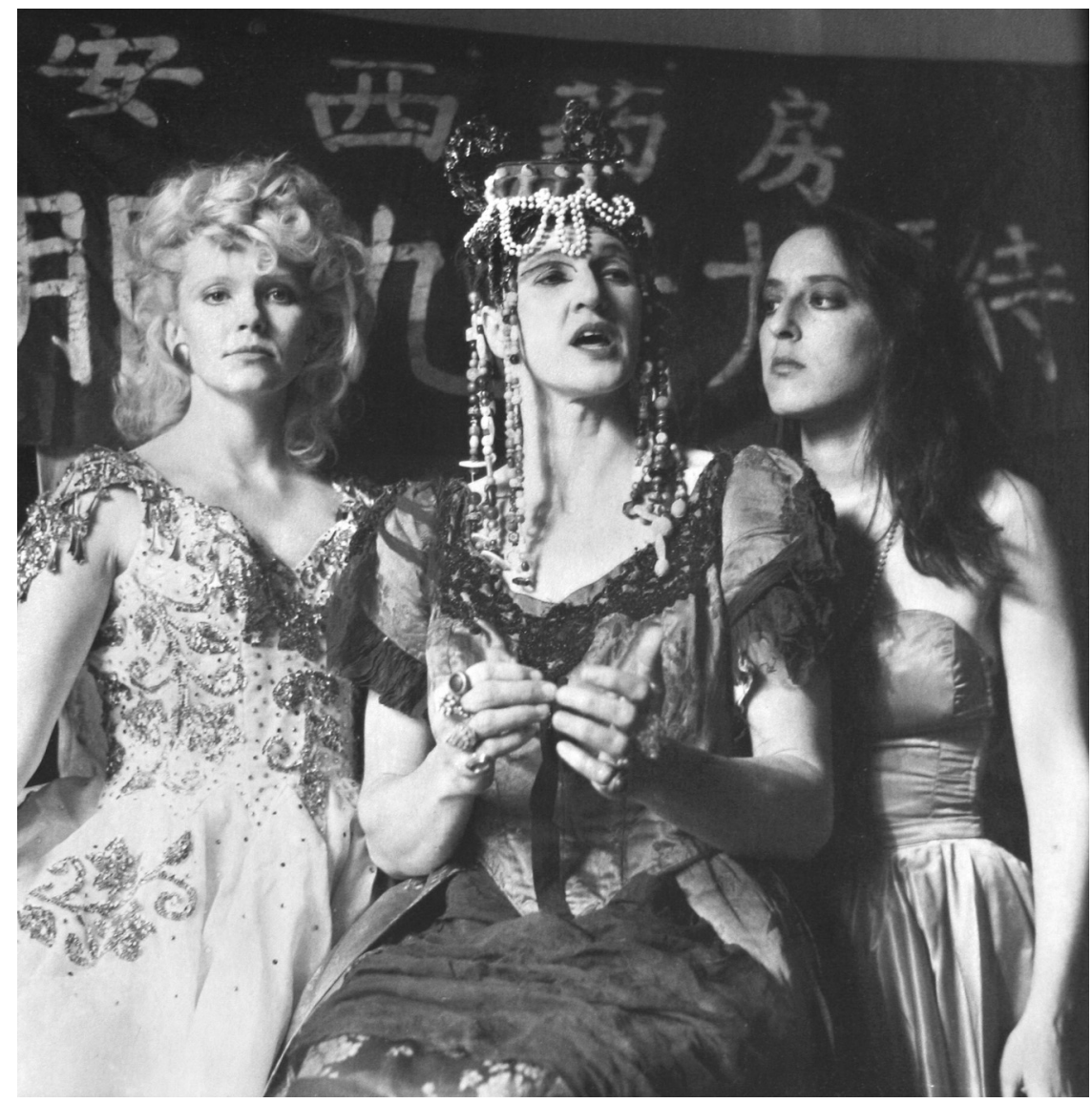

Figure I4: A scene from the Split Britches' play Upwardly Mobile Home, first staged at the WOW Café on East I Ith Street in I984. The piece depicts a troupe of actors who camp under the Brooklyn Bridge, performing plays and attempting to sell out and get rich in Reagan's America. In this scene, Tammy (Lois Weaver), Mom (Peggy Shaw), and LeVine (Deb Margolin) perform the 1926 melodrama The Shanghai Gesture.

character Tammy WhyNot. Shaw's solo pieces include You're Just Like My Father (I995), Menopausal Gentleman (I999), and most recently To My Chagrin (200I), which asks the astonishing question, how can a white, butch grandmother pass on the gift of masculinity to her beloved biracial grandson, across their differences of sex, age, and race?

Another troupe that incubated at WOW is The Five Lesbian Brothers, composed of Lisa Kron, Peg Healey, Moe Angelos, Babs Davy, and DominiqueDibbell, whose Voyage to Lesbos launched from WOW in 1989. The Brothers forged a style that collided cabaret and Brechtian modes of performance with moments of understated, often shockingly intimate, 


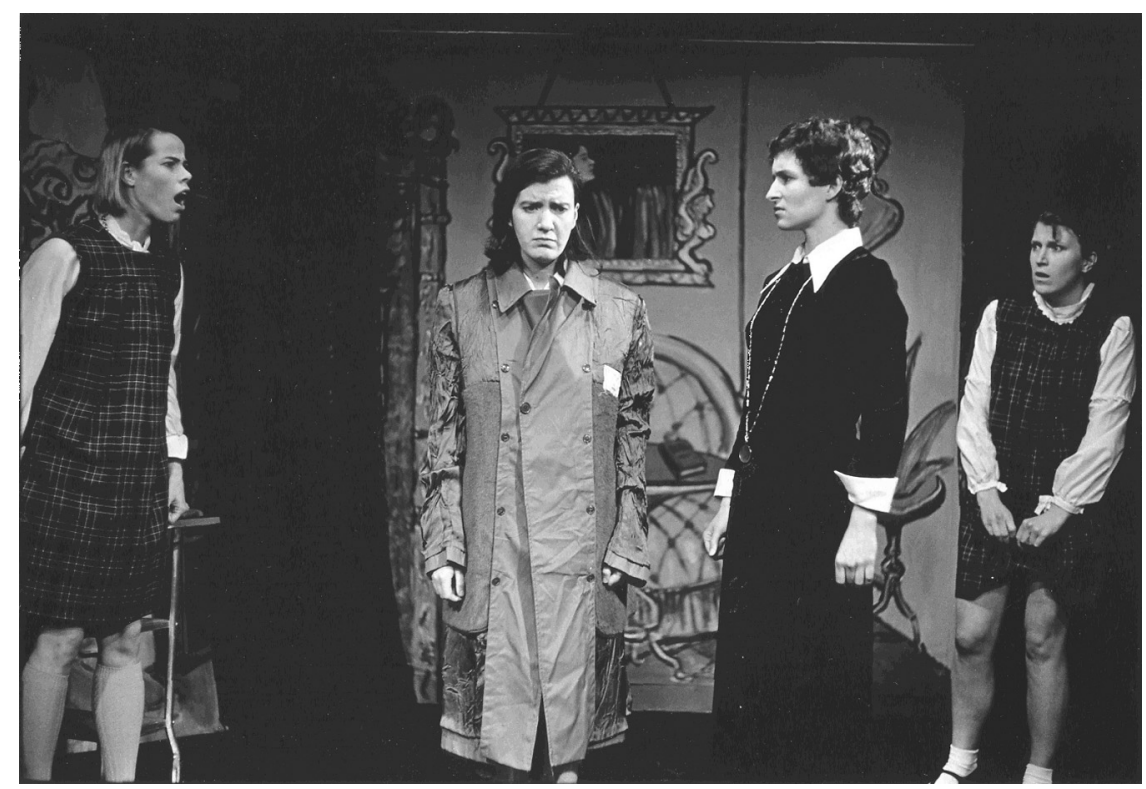

Figure I 5: The Five Lesbian Brothers performing Brave Smiles at the WOW Café in I992. Left to right: Babe (Peg Healey), Thalia (Maureen Angelos), Frau von Pussenheimer (Dominique Dibbell), Millicent (Babs Davy). In this moment (Act I, scene 2), Millicent has just found Thalia, the "new girl," wandering by the river, and has brought her to school. The scene includes several comments on Thalia's coat, which has been turned inside-out by boys who tormented her. The real reason that the coat is inside-out, however, is that the Brothers were touring and had only one coat available as a costume, and another character needed to wear it in Act II. Director Kate Stafford suggested turning the coat inside-out in the first Act to create the appearance of two coats, and that directorial choice became embedded in the script.

closely observed realism. Foregrounding sexual desire, irreverence toward all orthodoxies (including lesbian and feminist orthodoxies), and a commitment to explore whatever frightened them most, the Brothers created Brave Smiles (1992; see Figure I5) and The Secretaries (1994), both of which parodied films that stereotype lesbians, and Brides of the Moon (1997), which satirized the nuclear family from the vantage point of outer space. The Brothers' most realistic drama, Oedipus at Palm Springs (2005), re-imagined the Greek myth through the eyes of Jocasta. Brother Lisa Kron has pursued a solo career as a playwright and performer with works including IO I Humiliating Stories (I993), 2.5 Minute Ride (I996), and most recently Well, which opened on Broadway in 2006 and received two Tony nominations. Kron has developed a unique mode of drama in which a character, often named "Lisa Kron," steps on stage intending to tell the audience a self-serving story, but circumstances intervene - other actors refuse to cooperate, the set falls apart, the storyteller fails to hit a 
mark - and a different, messier, and ultimately far more important story erupts.

WOW's most celebrated alumnae also include Alina Troyano and Holly Hughes. Troyano, who often performs under the name Carmelita Tropicana, writes that she came to New York's downtown theater scene in a "search for Kunst" - a pun upon the German word for "art" as well as another Anglo-Saxon term. ${ }^{17}$ She found both entities at WOW, where she met, to her delight, "feministas with a sense of humor!" including the members of Split Britches. ${ }^{18}$ Troyano became a member of the WOW collective, studied playwriting with Maria Irene Fornes, and developed the persona of Carmelita Tropicana, a performance artist who sports "red lipstick, a beauty mole, an accent," and an evening gown that "disidentifies," as José Esteban Muñoz puts it, with stereotypes of Cuban culture. ${ }^{19}$ Troyano performs solo in the alter ego of Tropicana as well as other characters; in Milk of Amnesia Leche de Amnesia (1994), for example, she plays multiple roles including Carmelita Tropicana and a Cuban man named Pingalito (a pun on Cuban slang for penis).

Troyano performed her first role at WOW in Holly Hughes's first play, The Well of Horniness (1983). This campy take-off on detective drama (and loose parody of Radclyffe Hall's tortured lesbian novel, The Well of Loneliness [I928]) resulted, Hughes said, from "economic desperation and too many Bloody Marys." ${ }^{\circ}$ The original cast included Hughes, Peggy Shaw of Split Britches, and Moe Angelos of The Five Lesbian Brothers; Troyano played a Sapphic sorority sister with hilarious lines such as, "You sit in a puddle, or you just glad to see me?" ${ }^{21}$ The playwright, Holly Hughes, was a white lesbian who had recently moved from Michigan to New York in search of a career in the visual arts. Attracted to WOW's anarchy, Hughes launched a career as a playwright and performance artist. She followed The Well of Horniness with Dress Suits for Hire (1987), which Lois Weaver and Peggy Shaw performed, World Without End (I989), an elegy for her mother, and other solo performances at and beyond WOW.

In the late I 980 , Hughes applied for a grant from the National Endowment for the Arts (NEA). The NEA's peer reviewers recommended that she receive this much-needed funding, and made the same recommendation for gay male performance artists Tim Miller (who co-founded New York's avant-garde theater PS I 22) and John Fleck, and heterosexual feminist performance artist Karen Finley. But in I990 John Frohnmayer, chairman of the National Endowment for the Arts (NEA), vetoed these grants solely on the basis of the queer and sexual content of the artists' work; thus he defunded Hughes, Miller, Fleck, and Finley. Under the leadership of Senator Jesse Helms, the NEA then impelled all grant recipients to sign a pledge not to use federal 
monies for art that some unspecified individual, at some unspecified time, might deem obscene or blasphemous. Some theatrical artists refused to sign the pledges and rejected NEA grants; others, including Ellen Stewart of La Mama, continued to accept funding. The four original defunded artists, subsequently dubbed "the NEA four" (or, occasionally, "three queers and Karen Finley"), joined with the American Civil Liberties Union to sue the federal government. The group won a settlement equal to the grants plus court expenses, but the Supreme Court overturned part of that ruling in 1998. Hughes wrote about the fiasco in a solo performance piece, Preaching to the Perverted (2000), a cutting meditation on democracy and denigration.

The founding and flourishing of Spiderwoman, Split Britches, and WOW figured in a larger movement in the I970s and I980s, as second-wave feminism and gay liberation fostered a new generation of lesbian and gay plays, playwrights, and theatrical companies off- and off-off-Broadway. Magaly Alabau and Ana Maria Simo founded Medusa's Revenge in I976; and Doric Wilson founded TOSOS (The Other Side of Silence) in 1972. ${ }^{22}$ Lesbian theaters and gay theaters such as these opened in close geographical proximity in New York City, but as Don Shewey writes, "they may as well have been on different planets." Separate gay and lesbian theaters "occupied completely distinct social circles and aesthetic realms, with no conscious or unconscious solidarity around any shared notions." ${ }^{23}$ In retrospect, however, these separate theaters may have had much in common: Simo commented in 1995 that she now saw "Medusa's Revenge, in a way, as closer to what Doric Wilson was trying to do. That is, it was a community-based thing." ${ }^{24}$ One venue that staged both gay and lesbian plays was The Glines, a primarily gay male theater that opened in 1976 and that premiered Jane Chambers's Last Summer at Bluefish Cove in I980. ${ }^{25}$ Last Summer is a moving portrait of a terminally ill lesbian who, while vacationing with a community of lesbian friends, falls in love with a straight woman. Chambers's exceptionally adept use of realism appealed to lesbians who were eager to see their lives reflected on stage; as a result, Chambers's plays, including A Late Snow (1974) and The Quintessential Image (I982), continue to be staged thirty years later.

Ellen Stewart, a straight African American woman, founded La Mama Experimental Theater Club (La Mama E.T.C.) in I96I. Since its inception, this East Village theater has fostered and produced drama and performance by and about diverse GLBTQ people. The first production was Andy Milligan's adaptation of Tennessee Williams's short story, "One Arm"; a decade and a half later, La Mama premiered each of Harvey Fierstein's three one-acts that later combined to constitute Torch Song Trilogy, a play about a Jewish drag queen and his relationships with his lover, mother, and son. 
Torch Song Trilogy played at The Glines in I98 I, where it starred Fierstein, Matthew Broderick, and Estelle Getty, and then moved to Broadway in I 982. Other playwrights and performers who have worked at La Mama include Maria Irene Fornes, Remy Charlip, Marga Gomez, Stacy Makishi, Ethyl Eichelberger, and Cino alumni Robert Patrick, William Hoffman, and JeanClaude Van Itallie. "Eighty percent of what is now considered the American theater," Harvey Fierstein once said, "originated at La Mama." 26

In the I980s, AIDS devastated New York, and dramatists responded to the epidemic with activist plays. In I 985 , New York's theaters premiered William M. Hoffman's As Is and Larry Kramer's The Normal Heart - two of the first of what came to be known as the genre of "AIDS plays." ${ }^{27}$ No clear line divides AIDS theater from AIDS activism, and it is no accident that Larry Kramer both authored one of the most famous AIDS plays and co-founded the Gay Men's Health Crisis and ACT UP (the AIDS Coalition to Unleash Power), a direct action group that embraces a confrontational style of public demonstration and civil disobedience. ACT UP's theatrical strategies overlap with and influence those of other activist groups, including WHAM (Women's Health Action and Mobilization, with which ACT UP collaborated on the famous "Stop the Church" demonstration at New York's St. Patrick's Cathedral in I989), the Lesbian Avengers (a group that continues to draw attention to demonstrations through trademark performances of fire-eating), and Queer Nation (whose anonymous manifestos of I990 and I99I were probably authored by members of ACT UP).

Two of the most celebrated shows of the I990s revolved around AIDS, and in each the setting of New York was palpably significant to the point that one could read the city as a character. In Jonathan Larson's rock musical Rent (1996), impoverished artists and musicians - many gay, lesbian, or bisexual; many HIV+ - struggle to create art and keep roofs over their heads in the rapidly gentrifying East Village. Larson, who was heterosexual, publicly acknowledged that his musical adapted Giacomo Puccini's nineteenth-century opera La Bohème, with AIDS replacing that opera's scourge of tuberculosis. Privately, Larson allegedly acknowledged another, uncredited and uncompensated contemporary source: lesbian fiction writer and playwright Sarah Schulman's 1990 novel, People in Trouble. ${ }^{28}$ As Schulman puts it, "Basically Rent had two plots: the straight half was from Puccini, and the gay half was from me." ${ }^{29}$ The musical's engaging and affecting music, and its sympathetic portrayal of queer and HIV+ people, earned Rent critical acclaim and numerous accolades, including the 1996 Pulitzer Prize, four Tony Awards, six Drama Desk Awards, and three OBIEs. Rent troubles some queer audiences, however, with the way in which it locates heterosexuals at the center of the AIDS crisis, portrays queers as grateful 
for straights' assistance, and ultimately suggests that queer people deserve sympathy because they are no different from heterosexuals.

Tony Kushner's two-part saga, Angels in America: A Gay Fantasia on National Themes, stages gay life in specific locations in New York - Central Park, the Hall of Justice in Brooklyn, an abandoned lot in the South Bronx but leaps from those real locations to a fantastically imagined Antarctica and a no-place in which one character's pill-induced hallucination merges with another's dream. The characters are at once individuals and sweeping gestures toward desirous dreamers of "America": immigrants, Jews, gay men, people with AIDS, Mormons, and, nightmarishly, the historical figures of closeted homophobe Roy Cohn and his victim, Ethel Rosenberg.

Part One: Millennium Approaches premiered in San Francisco in I99I and traveled to New York (in a 1993 production directed by George C. Wolfe) via Los Angeles and London, and in all locations it generated unparalleled excitement for its operatic re-imagining of America. Larry Kramer described Kushner's play as "drunk on ideas, on language, on the possibility of changing the world"; John Lahr called Part Two: Perestroika a "masterpiece" and declared that "[n]ot since [Tennessee] Williams has a playwright announced his poetic vision with such authority on the Broadway stage." 30 Part One's honors of 1993 alone include the Tony Award for Best Play, the Pulitzer Prize for Drama, the New York Drama Critics' Circle Award for Best Play, and the Drama Desk Award for Best Play; Part Two: Perestroika won the Tony Award for Best Play and the Drama Desk Award for Outstanding Play. Critics hailed the saga's "breathtaking scope and intellectual, political, and theatrical daring," but the play often becomes the object of censorship efforts. ${ }^{31}$ Among gay scholars, critics, and audiences, Kushner's triumph marked "a turning point in the history of gay drama, the history of American drama, and of American literary culture ... remov[ing] from the closet once and for all the enlivening relationship of gay culture and American theater and the centrality of the homosexual gaze in American literature." ${ }_{32}$

The critical and popular acclaim for Angels in America was extraordinary but not isolated. During the final decade of the twentieth century, a small coterie of lesbians and gay men including Kushner, Margaret Edson, George C. Wolfe, Jane Wagner, Charles Busch, Terrence McNally, Paula Vogel, Lisa Kron, and Craig Lucas authored plays - some with queer characters, some without - that enjoyed substantial runs in major theaters. The public comings-out of well-known performers such as Rosie O'Donnell, Ellen Degeneres, Sir Ian McKellan, Rupert Everett, and Lily Tomlin suggested to some that the twenty-first century would constitute a "post-gay" period in which sexual identity was irrelevant. 
The 2003 Tony Awards Show appeared, to some, to inaugurate this "postgay" era: in that year, gay men nearly swept the Tony Awards, prompting Frank Rich, critic for the New York Times, to call the Awards ceremony the "first live gay network reality show." Open gay men and lesbians had won Tonys before (Cherry Jones, for example, thanked her partner while accepting a Tony for Best Actress in I995). In 2003, however, the openly gay awardees reached critical mass for the first time. That year, actor and playwright Harvey Fierstein was named Best Leading Actor in a Musical for his drag role in Hairspray (which earned the title of Best Musical, as well as six other Awards); and the Tony for Best Play went to Take Me Out, the story of a gay ballplayer. It was Marc Shaiman and Scott Wittman, however, who stole the show when they accepted their award for Best Original Score for Hairspray. The two men lingered in a loving kiss on the lips. Then Shaiman said to Wittman, his partner of twenty-five years: "I'd like to declare in front of all these people, I love you and I'd like to live with you the rest of my life." ${ }_{3}$ The New York Times serenely described the Awards show kiss as theatrical "business as usual," and most audience members seemed to agree. Of the eight million people who watched the Tony Awards that year, only ten telephoned CBS to complain about gay visibility at the ceremony, and only sixty-eight emailed the network.

The spectacle of white gay male theater practitioners pledging long-term domesticity apparently delivered little shock value, even if they prefaced that declaration with a tender kiss. As playwright Richard Hall has pointed out, however, gay content on stage generally receives the least censure when sexuality is couched within a larger affirmation of long-term relationships and nuclear families. The I983 Tony Award-winning musical La Cage Aux Folles, for example, challenged audiences to respect and sympathize with gay male protagonists, including a drag queen, but the show's plot revolved around one of the gay men's relationship with his heterosexual son on the occasion of the son's engagement. The popular success of Torch Song Trilogy, Hall points out, would seem unlikely, given its "brilliant scene in a backroom bar in which [protagonist] Arnold Beckoff mimes getting fucked while managing, among other things, to light a cigarette" - but the larger arc of the play "tells critics and [the straight] public what they hope to hear: gay people are just like straight people; all they want is a loving spouse, nice in-laws and a kid who gets good grades." 34 In that context, Shaiman's wish to "live with [Wittman] for the rest of my life" may neutralize rather than magnify the political impact of the kiss.

Race and ethnicity, as well as familial configuration, can undermine a gay or lesbian play's chances for mainstream success. Chicana playwright Cherríe Moraga notes that the transgressive sexual and political content 
of Angels in America would play very differently in a Chicana lesbian context:

Of course, I loved [Angels in America], as did ... most of the theater-going public of the United States ... The play is undeniably and unabashedly queer and dangerously "commie" in perspective, which I relish and respect about Kushner's work. But what I anticipated would make the audience uncomfortable was precisely what made the audience hysterical. Every dick joke, even every Jewish dick joke, even every homosexual Jewish dick joke, tore the audience up. They weren't offended. They were entertained ... I look around at this Broadway audience, mostly straight, overwhelmingly White, upper middle class, of course: your typical theater crowd ... [T] o my amazement two guys start to "fuck" on stage (as Kushner describes it in the stage directions: "They fuck.") and everyone is fine with it ... So, I did a little private experiment. Every time I heard the word or a reference to "Jewish dick," I replaced it with "Mexican pussy.” Jewish dick ... Mexican pussy. Jewish dick ... Mexican pussy. Jewish dick ... Mexican pussy. And nobody was laughing. That's me on Broadway. That's my people on Broadway. That chilling silence. ${ }^{35}$

Jewish humor, Moraga astutely observes, is "synonymous with New York" and abundant on Broadway and television; therefore the Jewishness of Angels in America makes the play seem "translatable" even to "laughing lawyers and stockbrokers in the audience who may very well cry at the real news of having a real gay son." ${ }^{6}$ In other words, the Jewish humor serves as the drama's affective connector that makes the play feel familiar and accessible to audiences who do not, in fact, have any meaningful connections to Jews, queers, or Marxists. Because of racism and sexism, however, plays by and about gay men of color and lesbians of all races and ethnicities can feel, to straight white audiences, more unfamiliar and inaccessible than they actually may be.

When Moraga imagines one of her plays produced on Broadway, she hears "chilling silence" in response to her jokes about "Mexican pussy." But the most common form that silence takes is the refusal to produce works by gay men of color and lesbians in the first place. Supremely accomplished playwrights who have never been produced on Broadway include white lesbian Paula Vogel, who won a 1998 Pulitzer Prize for How I Learned to Drive; Latino gay man Luis Alfaro, who received a MacArthur Fellowship, commonly known as a "genius grant," for his playwriting and performing; Asian American gay man Chay Yew, the winner of the London Fringe Award and the George and Elisabeth Marton Playwriting Award, whose work has “significantly shifted the poetic and political landscape of both Asian American theater and gay theater"; 37 and Chicana lesbian Cherríe Moraga, recipient of the I 993 Pen West Award for Drama, the I993 NEA Theater Playwrights' 
Fellowship, the 200I Scholars Award from the National Association for Chicana and Chicano Studies, Lifetime Achievement Awards from Ellas in Acción, and (with Gloria E. Anzaldúa) the 200I Bode-Pearson Prize for Outstanding Contributions to American Studies - one of the oldest and most prestigious honors awarded by the national American Studies Association.

Many open lesbians and gay men assume leadership positions in major regional and off-Broadway theaters: Luis Alfaro spent a decade as Associate Producer, Director of New Play Development, and co-director of the Latino Theater Initiative at the Mark Taper Forum in Los Angeles; George C. Wolfe served from I993 to 2004 as Artistic Director and Producer at the New York Shakespeare Festival and the Public Theater; Brian Freeman, co-founder of the brilliant San Francisco-based performance troupe, PomoAfroHomos (postmodern Afro-American homosexuals), recently founded the Playwrights' Lab at the New York Public Theater, where he developed a play based on the life of Bayard Rustin, a gay African American man who organized the 1963 Civil Rights march on Washington, DC; and Megan Terry and her life partner Joanne Schmidman operate the Omaha Magic Theater, which Schmidman founded in 1970 and which Terry has served as a playwright since I974.

Some lesbian and gay theaters, such as the Alice B. Theater in Seattle, have closed in recent years, but others continue to produce work, often despite breathtaking economic challenges. Primarily or exclusively queer theaters include Theater Rhinoceros in San Francisco; Theater Offensive in Boston; Bailiwick in Chicago; Buddies in Bad Times Theater in Toronto, Canada; TheaterOut in Anaheim, California; Triangle Productions in Portland, Oregon; and many others. As funding for the arts becomes scarcer, colleges and universities become increasingly important to American theater, including lesbian and gay theater. Colleges and universities provide crucial venues for solo actors and small troupes, who often tour with offerings that include linked performances and master classes in playwriting or acting. Theater has also become a key site of community and support for queer youth: in Boston, for example, members of the True Colors Out Youth Theater co-create and perform original shows.

Broadway declares itself the sun around which off-Broadway, offoff-Broadway, and regional theaters orbit, but GLBTQ theater practitioners move in multidirectional trajectories that challenge the primacy of not only Broadway, but also heterosexuality, realism, and normalized configurations of gender and family. When padlocks barred gay and lesbian content from Broadway, some queer people clandestinely picked the locks while others created a downtown scene of unrivaled brilliance and beauty. When AIDS decimated New York's gay communities, GLBTQ people 
organized, launched street activism, and channeled rage and grief into stunning theatrical works that foundationally changed American theater, including Broadway. When performers and playwrights are repeatedly defunded, GLBTQ theater practitioners find and create unlikely venues for performance. The New York Times may yawn at a supposedly "postgay" moment in which gay men and lesbians are welcome to the extent that they affirm monogamy, parenthood, and typical modes of gender but radical queers continue to critique, defamiliarize, and explode these norms, and to tell the complex and messy truths of our lives. Against all odds, radical queers, especially lesbians of color, stage "[b]rief flashes of image, word, sound that respond finally to that most censored desire." These moments are, in Cherríe Moraga's words, "ruptures of queer heroism." When we witness these ruptures, these world-making glimpses at the world that exists and the world we have the power to create, we are "breathless at the self-recognition." ${ }_{3} 8$

\section{NOTES}

Parts of this chapter are adapted from the introduction to Cast Out: Queer Lives in Theater, ed. Robin Bernstein (Ann Arbor, MI: University of Michigan Press, 2006), pp. I-22.

I. On the history of drag performance, see Laurence Senelick, The Changing Room: Sex, Drag and Theater (New York: Routledge, 2000).

2. Kaier Curtin's "We Can Always Call Them Bulgarians": The Emergence of Lesbians and Gay Men on the American Stage (Boston, MA: Alyson Publications, 1987) includes respective chapters on God of Vengeance, The Captive, and The Drag. See also Harley Erdman, "Jewish Anxiety in 'Days of Judgment': Community Conflict, Antisemitism, and the God of Vengeance Obscenity Case," Theater Survey 40:I (May I999): 5 I-74.

3. Curtin, "We Can Always Call Them Bulgarians", p. Ioo.

4. Richard Schechner, "Who's Afraid of Edward Albee?" Tulane Drama Review 7:3 (I963): 7-IO; Robert Brustein, Seasons of Discontent: Dramatic Opinions 1959-1965 (London: Jonathan Cape, 1966), p. 29; Philip Roth, "The Play that Dare Not Speak its Name," New York Review of Books 4:2 (February 25, 1965).

5. Stanley Kauffmann, "Homosexual Drama and its Disguises," New York Times (January 23, I966): 93. Howard Taubman forwarded similar claims in "Not What it Seems: Homosexual Motif Gets Heterosexual Guise," New York Times (November 5, I96I): II:I.

6. Ibid. See also Frank Marcus, The Killing of Sister George (1965), in Gay Plays: The First Collection, ed. William M. Hoffman (New York: Avon Books, I979), pp. 337-4II; Jean-Paul Sartre, No Exit, trans. Paul Bowles (original French edn. [Huis Clos] published 1944; New York: Samuel French, 1958); and Lillian Schlissel, ed., Three Plays by Mae West: "Sex," "The Drag," "The Pleasure Man” (New York: Routledge, I997). 
7. Kauffmann, "Homosexual Drama and its Disguises," 93.

8. See Alan Sinfield, Out on Stage: Lesbian and Gay Theater in the Twentieth Century (New Haven, CT: Yale University Press, I999), pp. 300-02.

9. Don Shewey, "Pride in the Name of Love: Notes on Contemporary Gay Theater," Introduction to Out Front: Contemporary Gay and Lesbian Plays, ed. Don Shewey (New York: Grove Press, 1988), p. xii.

Io. Meg Swanson with Robin Murray, Playwrights of Color (Yarmouth, ME: Intercultural Press, I999), pp. 76-89. See also Ann Haugo, "Weaving a Legacy: An Interview with Muriel Miguel of the Spiderwoman Theater," in The Color of Theater: Race, Culture, and Contemporary Performance, ed. Roberta Uno with Lucy Mae San Pablo Burns (London and New York: Continuum, 2002), pp. 2I8-34; and Charlotte Canning, Feminist Theaters in the U.S.A.: Staging Women's Experience (London and New York: Routledge, I996), pp. 82-84, 93-99, I65-69. Spiderwoman maintains an excellent website, containing many production stills, at staff.lib.muohio.edu/nawpa/ spdrwmnarchv.html.

I I. Ann Haugo, "Native American Drama," in A Companion to Twentieth-Century Drama, ed. David Krasner (Malden, MA: Blackwell, 2005), pp. 34I, 342.

I2. Sue-Ellen Case, ed., Split Britches: Lesbian Practice/Feminist Performance (New York: Routledge, I996), pp. 4-5. As Case notes, "tales told in various critical essays, and in interviews, present various versions" of Weaver and Shaw's exit from Spiderwoman. These tales vary particularly in their assessment of the roles of race and sexuality in the split. See Rebecca Schneider's "See the Big Show: Spiderwoman Theater Doubling Back," in Acting Out: Feminist Performances, ed. Lynda Hart and Peggy Phelan (Ann Arbor, MI: University of Michigan Press, 1993), pp. 227-55; Jill Dolan, The Feminist Spectator as Critic (Ann Arbor, MI: University of Michigan Research Press, I988), pp. 7I, I36); and Case, ed., Split Britches, p. 5.

I3. See Alisa Solomon, “The WOW Café,” TDR 29: (Spring I985): 92-IOr for an oral history of the WOW Café. See also Case, ed., Split Britches, pp. 7-8.

I4. Dolan, Feminist Spectator, p. 72.

I 5. Peggy Shaw, "How I Learned Theater," in Cast Out, ed. Bernstein, p. 28.

16. Case collects many of these dramatic scripts in Split Britches.

I7. Alina Troyano, I, Carmelita Tropicana: Performing Between Cultures (Boston, MA: Beacon Press, 2000), p. xiii.

I8. Ibid., p. xiv.

I9. Ibid., p. xv, and José Esteban Muñoz, Disidentifications: Queers of Color and the Performance of Politics (Minneapolis, MN: University of Minneapolis Press, 1999). See especially ch. 5, "Sister Acts: Ela Troyano and Carmelita Tropicana."

20. Holly Hughes, introduction to The Well of Horniness, in Out Front, ed. Shewey, p. 222.

2I. Ibid., p. 228.

22. William M. Hoffman, Gay Plays: The First Collection (New York: Avon Books, I979), pp. xxxi, xxxii. See also "From the Invisible to the Ridiculous: The Emergence of an Out Theater Aesthetic: A Conversation among Moe Angelos, Susan Finque, Lola Pashalinski, Everett Quinton, Ana Maria Simo, and Doric Wilson, Moderated by Don Shewey," in The Queerest Art: Essays on Lesbian 
and Gay Theater, ed. Alisa Solomon and Framji Minwalla (New York: New York University Press, 2002).

23. Don Shewey, “'Be True to Yearning': Notes on the Pioneers of Queer Theater," in The Queerest Art, ed. Solomon and Minwalla, p. I33.

24. Ibid., p. 139.

25. Don Rubin and Carlos Solorzano, eds., World Encyclopedia of Contemporary Theater: The Americas (New York: Taylor \& Francis, 2000), p. 339.

26. Alvin Eng, “'Some place to be somebody': La Mama's Ellen Stewart," in The Color of Theater, ed. Uno and Burns, p. 135.

27. David Román points out that these two plays are sometimes falsely identified as "the earliest responses to AIDS in the theater," an error that "does a grievous disservice to such artists, playwrights, and theater collectives as Robert Chesley, Jeff Hagedorn, Rebecca Ranson, and San Francisco's A.I.D.S. Show collaborators, among others, whose AIDS performances were produced as early as I983" (Acts of Intervention: Performance, Gay Culture, and AIDS [Bloomington, IN: University of Indiana Press, I998], p. xx). Román devotes a full chapter of his book to theatrical interventions to the AIDS crisis in the early I980s. John M. Clum also treats AIDS drama in depth in Still Acting Gay: Male Homosexuality in Modern Drama (New York: St. Martin's Press, 2000).

28. Sarah Schulman, Stagestruck: Theater, AIDS, and the Marketing of Gay America (Durham, NC: Duke University Press, I998), p. I3.

29. Ibid.

30. Kramer quoted in Tony Kushner, Thinking about the Longstanding Problems of Virtue and Happiness (New York: Theater Communications Group, I995), rear cover; John Lahr, "The Theater: Earth Angels," The New Yorker (December I3, I993): I33.

3I. Jill Dolan, "Lesbian and Gay Drama," in A Companion to Twentieth-Century Drama, ed. Krasner, p. 498. On censorship and Angels in America, see John Houchin, Censorship of the American Theater in the Twentieth Century (New York: Cambridge University Press, 2003), esp. pp. 250-52 and 263-65.

32. John Clum, Acting Gay: Male Homosexuality in Modern Drama (New York: Columbia University Press, I992), p. 324.

33. Frank Rich, "Gay Kiss: Business as Usual," New York Times (June 22, 2003): ii:I.

34. Richard Hall, Three Plays for a Gay Theater and Three Essays (San Francisco, CA: Grey Fox Press, I983), pp. 173-74.

35. Cherríe Moraga, "The Art of Anger in América," in The Color of Theater, ed. Uno and Burns, pp. I 8 8-19.

36. Ibid., pp. I 8 , I I9, emphasis in original.

37. David Román, "Los Angeles Intersections: Chay Yew," in The Color of Theater, ed. Uno and Burns, p. 237.

38. Cherríe Moraga, "And Frida Looks Back: The Art of Latina/o Queer Heroics," in Cast Out, ed. Bernstein, p. 89. 